\title{
The Development of Ecclesiastical Particular Law in Canada
}

\section{Francis G. Morrisey}

Volume 50, numéro 1, 1983

Bilan de l'histoire religieuse au Canada

Canadian Catholic History: A survey

URI : https://id.erudit.org/iderudit/1007040ar

DOI : https://doi.org/10.7202/1007040ar

Aller au sommaire du numéro

Éditeur(s)

Les Éditions Historia Ecclesiæ Catholicæ Canadensis Inc.

ISSN

0318-6172 (imprimé)

1927-7067 (numérique)

Découvrir la revue

Citer cet article

Morrisey, F. G. (1983). The Development of Ecclesiastical Particular Law in Canada. Sessions d'étude - Société canadienne d'histoire de l'Église catholique, 50(1), 141-158. https://doi.org/10.7202/1007040ar

Tous droits réservés @ Les Éditions Historia Ecclesiæ Catholicæ Canadensis Inc., 1983
Ce document est protégé par la loi sur le droit d'auteur. L'utilisation des services d'Érudit (y compris la reproduction) est assujettie à sa politique d'utilisation que vous pouvez consulter en ligne.

https://apropos.erudit.org/fr/usagers/politique-dutilisation/ 


\title{
The Development of Ecclesiastical Particular Law in Canada
}

\author{
by Francis G. MORRISEY, O.M.I. \\ Saint-Paul University
}

Ottawa, Ont.

\section{INTRODUCTION}

The second Vatican Council, in its constitution on the Church, insisted on the significance of particular Churches in the Catholic Church. In paragraph 23, it states:

Collegial union is apparent also in the mutual relations of the individual bishop with particular churches and with the universal Church. The Roman Pontiff, as the successor of Peter, is the perpetual and visible source and foundation of the unity of the bishops and of the multitude of the faithful. The individual bishop, however, is the visible principle and foundation of unity in his particular church, fashioned after the model of the universal church. In and from such individual churches there comes into being the one and only Catholic Church. ${ }^{1}$

The individual or particular Church that interests us today in a particular fashion is the Church in Canada; we are especially concerned with the legislation passed by the leadership of the Church throughout the period of development of Catholicism in Canada. Four particular periods stand out in this area of legislative activity: the period of early synods and regional councils; the plenary council of Quebec and its application; legislation in the Vatican II period; application of the 1983 Code of Canon Law.

\footnotetext{
1 Vatican Council II, Constitution "Lumen Gentium", No. 23 in W.M. Abbott, ed., The Documents of Vatican II, London, Chapman, 1966, p. 44.
} 
We shall examine each of these periods in turn to note trends in the legislation and to see how the Church of tomorrow is being shaped through the legislative activity of the bishops, both in the particular churches and as part of the universal Church.

\section{THE PERIOD OF EARLY SYNODS AND REGIONAL COUNCILS}

Since there was only one diocese in Canada during the entire period of the French regime, the local legislation is diocesan in scope, even though it necessarily applies to the entire territory. Such legislation finds its more concrete expression in the enactments of synods. As the number of dioceses increased, the bishops began to legislate together in regional councils. While most of the councils took place in Quebec, a number of other such meetings were held elsewhere in the country up to the end of the nineteenth century.

\section{a. Synods in Quebec during the French regime}

Under Bishop de Laval, the first legislation was concerned with more particular problems, such as the sale of alcohol to the Indians (May 5, 1660), the regulation of funerals (July 10, 1661), tithes (November 10, 1663), reserved sins (April 21, 1669), as well as with the establishment of a Chapter, the Seminary, and the ecclesiastical court. Bishop de Laval, given the circumstances of the diocese, did not hold any synods during his term of office. This was left to his successor, Bishop de St-Vallier, who held the first one in Quebec City, November 9,1690 . Some 26 decrees were issued, concerning such matters as the offering of Mass in private homes, assistance at Mass on Sunday, norms for burials, relationship between pastors and churchwardens, prayers for the King and for the Church.

A second synod was held in Ville-marie (Montreal) on March 1011,1694 . Some 27 decrees were issued at the time; most of these were concerned with details, but some had special significance for the sacrament of penance. For instance, jurisdiction for hearing confessions extended only to a priest's parish, except when travelling in a place where there was no resident priest; it was to be renewed every three years. Pastors were reminded of the need of providing other priests at times to help with confessions and to assure peace of conscience for the faithful. 
A third synod was held in Quebec, February 27, 1698. In all, some 43 decrees were promulgated. They concerned observance of the Lord's day, organization of catholic schools in each parish, importance of music during the liturgy, and reservation of sins.

The fourth and final synod of the French Regime was again held in Quebec City, October 8, 1700, with some 33 decrees issued. Once again, specific reference is made to the sacrament of penance, and to the life and ministry of priests.

The decrees of the various synods were transposed to some extent into the Catechism of the Diocese of Quebec (1702) which presented a unified teaching, but did not wish to present a codified collection of laws. However, the Catechism clearly outlines the legislation of the Church on marriage impediments and similar matters. In practice, we must recognize that this Catechism and accompanying documents constituted the local legislation of the Church during the French Regime. It is good to recall that, during the same period, the Church universal did not have a unified Code of law, and such would not have been readily possible in Quebec at the time. ${ }^{2}$.

\section{b. The seven provincial councils of Quebec}

After the Catholic Church received its freedom to operate in Quebec, the number of dioceses increased and the bishops undertook certain forms of joint cooperation. The most publicized form of such was the provincial council, grouping all the bishops who were members of the ecclesiastical province. These councils were held in 1851, 1854, $1863,1868,1873,1878$ and $1886 .^{3}$

Among the trends to be noted in these councils, we could mention the gradual adoption of Roman practices and the growing centralization of Church activity. In 1851, for instance, the new Roman Ritual was made mandatory in all dioceses, replacing henceforth the revised ritual of the diocese of Quebec in use since 1704. The practical problems faced by the bishops were then treated officially: preparation of a new

\footnotetext{
${ }^{2}$ For further details on this matter, see James A. Schmeiser, "The Development of Canadian Ecclesiastical Provinces, Councils, Rituals, and Catechisms", in Studia Canonica, 5 (1971), pp. 136-165.

${ }^{3}$ On this matter see J. Grisé, Les conciles provinciaux de Québec et l'Église canadienne (1851-1886), Montréal, Fides, 1979, 454 pp.
} 
catechism, obligation to follow the moral teachings of St. Alphonsus (against rigorism), love of the Holy Father promoted, especially during a time of strife in Europe (1870). After Vatican I, the bishops stressed the notion of papal infallibility defined at the Council. Parents were to be refused absolution if they sent their children to public schools. The independence of the Church as a perfect society was restated in 1873 , using the vocabulary of the time.

In the last two councils, we notice once again a rather strong preoccupation with moral issues; the bishops condemned a number of sins against virtue: dancing walses, polkas, walking in the night, intemperance, tobogganing, snow-shoeing and so forth.

It is relatively easy to trace the influence of various trends in public life and in society as we read the decrees promulgated by the Fathers; they range from matters relating to the internal life of the Church (legislation regarding the reception of the sacraments), to politics, to the role of the Holy Father, and, finally, towards a moralistic approach which so characterized the Church at the end of the nineteenth century, possibly under the influence of the Victorian age.

\section{c. Other councils held outside Quebec City}

In addition to the seven councils of Quebec, there were also councils held in Halifax, Toronto, Saint Boniface and Montreal.

The Council of Halifax (1857) showed special concern for the purity of the faith and for Catholic education. We also note a condemnation of abortion, something that had been mentioned in the Quebec legislation also. ${ }^{4}$ The council could not resist the temptation of entering into details and so it is not surprising to see norms against priests attending horse races, helping relatives with Church money, being absent from their rectories without the bishop's permission.

The Council of Toronto (1875) shows special interest for the pastoral care of the sick and of prisoners; the bishops were also especially concerned with the problems surrounding Catholic education. At the same time, they established norms regarding the salaries of priests, norms which remained substantially in effect in Canada until after Vatican II : pastors could retain all stole fees, one-half of the funeral fees, the Christmas and Easter collections, and the clergy dues.

${ }^{4}$ Cf. J. Grisé, op. cit., pp. 299, 303. 
The Council of Saint Boniface, held in 1889, was of special interest in a number of ways. It was the first legislative gathering of bishops in Western Canada; all the participants were members of the Congregation of the Oblates of Mary Immaculate. Ages for first communion were determined, mixed marriages forbidden, permission of the bishop was required before building churches or contracting debts. For the first time in legislation, we note a prescription to the effect that church property is $t$ ) carry sufficient insurance.

The Council of Montreal, 1895, promulgated the same type of decrees.

Looking at the decrees today, we note that they were not of earthshattering proportions. Nevertheless, they established the bases for a fruitful celebration of the sacraments and a good ordering of the Catholic community. But it would seem that the greatest benefit to derive from such gatherings was that the bishops began to meet regularly and work together, thus preparing the way for the day when they would be acting regularly as an Episcopal Conference, and as a group, without one or two bishops being considered the leaders of the Church. The road towards collective leadership has been a hard one, a road that even today seems to have its bumps, ruts and detours.

\section{THE PLENARY COUNCIL OF QUEBEC AND ITS APPLICATION (1909)}

One of the first legislative activities of the bishops of Canada that extended from the Atlantic to the Pacific, was the holding of the Plenary Council of Quebec in 1909. Because of the significance of this event, it requires more detailed study.

\section{a. Preparation for the Council}

The question of a Canadian Plenary Council was already posed in 1876 when Canada consisted of only four ecclesiastical provinces. First definite reference to the council is found in 1902 when the Apostolic Delegate to Canada wrote to the Canadian Archbishops concerning the holding of such a gathering. He pointed out the many advantages of such an assembly: the elaboration of a collection of ecclesiastical laws which would be adapted to the place, the time, and the circumstances; which would define in a precise manner the rights and the 
responsibilities of all Catholics; which would give more strength to ecclesiastical discipline and would in a special way provide a norm to solve difficulties.

In 1903, the Archbishop of Halifax, Archbishop O'Brien, then dean of the Archbishops, notified his colleagues of the desire of the Sacred Congregation for the Propagation of the Faith and suggested that the preparatory work could be accomplished by a commission of priests, with each Archbishop choosing two. The plan that would be elaborated by this commission would then be submitted to the examination of the Archbishop and his suffragans. Some four months later, March 2, 1904, the first commission of the representatives of the Archbishops met in Ottawa. They studied the general plan of the Council, discussing the project that had already been prepared by $\mathbf{M}^{\mathrm{sgr}}$ C.A. Marois, Vicar General in Quebec, and the elected president of the commission. The participants noted a lack of unity in the drafts and asked to have the documents sent to all the bishops for study by their canonists and theologians. The committee met again in October 1905 and finalized the drafts which were first sent to the bishops on February 16, 1905. Again, a lack of unity in the development was mentioned, and a request was made that the decrees be shortened. $M^{\text {sgr }}$ Louis-Adolphe Paquet was eventually entrusted with the task of coordinating the documents.

In 1908, the schemas were ready and it was thought possible to hold the Council in the near future. However, there were certain hesitations about holding it at that time because of the impeding promulgation of the Code of Canon Law. However, on February 17, 1909, Cardinal Gennari, Prefect of the Sacred Congregation of the Council, charged the Apostolic Delegate to convoke the Council as soon as possible. The opening date was subsequently fixed for September 19, 1909. In the letter issued by the Archbishop of Quebec, June 27, 1909, it was stated that the aim of the Council was to correct errors, repress abuses, indicate current dangers to faith and morals, regulate all that concerns cult and discipline, destroy vice, spread everywhere holy ideas, and establish the honour of the practice of Christian virtues. ${ }^{5}$

\section{b. The Council and its decisions}

The solemn opening took place on September 19, as announced, with the Council in session for six weeks. The final decrees were read on November 1, 1909. They were then submitted to the Holy See

\footnotetext{
${ }^{5}$ Most of the above is taken from James A. Schmeiser, loc. cit., pp. 157-161.
} 
for confirmation. Authorization to publish was granted on April 30, 1911, without substantial changes. The official text was published in June, 1912. It contained the acts of the Council and 688 conciliar decrees, the pastoral letter of the Fathers of the Council, both in English and in French, and the pontifical documents. The decrees had been officially promulgated by the Apostolic Delegate on April 25, 1912. The legislation extended to all dioceses in Canada, except those of Newfoundland. At that time, Newfoundland was separated both politically and ecclesiastically from the rest of Canada. However, a titular Archbishop, Ronald McDonald, retired bishop of Harbour Grace, attended the Council and signed its decrees.

As all other Councils, the Plenary Council of Quebec studied the dangers threatening the Church and its faithful, and the means to serve better the Gospel and the Church; however, it is significant that it also studied problems particular to its territory. This is manifested not only in the decrees of the Council, but also in the Pastoral Letter of the Fathers where they discussed the Christian spirit in the individual, in the family, and in society. When speaking of private life, the Fathers made particular reference to the model of the Christian life, the characteristic features of the Christian life, and its sources. It was particularly in this section that they made reference to various aspects of the liturgy, with special reference to the Eucharist.

The importance of the first Plenary Council is difficult to evaluate, but it is certain that it has been the main guide in particular legislation for Canada. The fact that the religious leaders from coast to coast came together to discuss the development of the Canadian Church was in itself a great event when we consider the divisions among the hierarchy in the last half of the nineteenth century. At that time, there were 34 Archbishops, Bishops, Vicars and Prefects Apostolic. There were eight ecclesiastical provinces, 29 regularly constituted dioceses, 3 vicariates and 2 prefectures.

The promulgation of the Code of Canon Law in 1917 - the world was still in the throes of a universal conflict - took away some of the impact of the particular legislation. Indeed, with a few exceptions, the decrees became rather obsolete since all attention was focussed more on the universal legislation which the Church had received for the first time in codified form, than on the local laws which were not provided for too readily in the Code. 
Norms regarding studies in preparation for ordination remained in effect until Vatican II (Nos. 168, 173, 175, 177, 179, 184 and 185). Special norms regarding the hearing of confessions throughout the country remained in effect after the promulgation of the Code, as well as regulations concerning the administration of temporal goods. Looking at such details now, they do not seem to have been of major importance. Nevertheless, they too helped shape the community of believers and provided for a consolidation of Church activity as it prepared to embark upon an era of expansion and consolidation of its authority in the aftermath of World War I.

The greatest advantage that was to derive from the Council was an indirect one. The bishops agreed to continue with some kind of regular meeting to retain contacts. This eventually led to the establishment of the episcopal conference for the country. ${ }^{6}$

Indeed, after the Plenary Council, the Archbishops decided to hold annual meetings. These began in November 1911, in Ottawa, and were held on the first Wednesday of October. In 1928, all the bishops met in Quebec under Cardinal Rouleau, and agreed to meet at five year intervals; in fact, they met in 1933, 1938 and 1943. In October 1943, they requested that "an organ to interpret the mind" of the hierarchy be established. It was proposed to hold a meeting every two years. A national board was elected at that time, consisting of the Archbishop of Quebec, two French and two English-speaking bishops. A permanent secretariat was established on January 3, 1944. On August 20, 1946, the Holy See gave permission to prepare a constitution which was approved in June 1948 for five years. It was decided at that time that the meetings of the Conference would be held in Ottawa, where the representative of the Holy See resides. The first constitution was given definitive approval on January 23, 1955.

\section{c. Implementation of the Conciliar decisions in Canada}

The 1917 Code of Canon Law provided for diocesan synods and provincials councils. A small number of such were held, but never according to the frequency envisaged by the Code. Nevertheless, the bishops were able to enact a number of legislative documents applying certain canons to Canadian situations. Among the particular actions of

\footnotetext{
${ }^{6}$ Cf. Bernard A. Prince, "Foundation of the Episcopal Conference in Canada", in Studia Canonica, 1 (1967), pp. 97-109.
} 
the bishops, their efforts at reorganizing the matrimonial tribunals deserve special mention. The Code had called for tribunals to be established in each diocese, with qualified personnel and support available. However, most of the dioceses were unable to provide the personnel; furthermore, the number of cases were relatively rare.

The Holy See had recently reorganized the tribunals in Italy and the Philippines, establishing regional courts instead of diocesan ones. This enabled the courts to function more smoothly and reduced the demands on personnel. On May 13, 1946, the Holy See agreed to the bishops' request and established regional tribunals in Vancouver, Regina, Toronto, Ottawa, Montreal, Quebec City and Halifax. ${ }^{7}$ Later on, a new court was opened in Edmonton (1952). ${ }^{8}$ While the number of cases processed was relatively small in number, the operation of the courts on a regional basis proved that forms of inter-diocesan cooperation could be advantageous for all. Such undertakings were then extended to other areas of Church life. Arrangements were also made to establish a Military Vicariate in the country. The formal establishment of a separate entity was authorized by the Holy See on February 17, 1951.

Norms were issued on various occasions concerning ecclesiastical attire in the country. Even before the Plenary Council, the roman collar had been substituted for the rabat (November 1, 1875) in the Archdiocese of Quebec, in accordance with the practice established informally in other dioceses. ${ }^{9}$ The Plenary Council, in decree No. 215, asked that the cassock be maintained where the custom existed; otherwise, a black suit extending to the knees was to be used. In 1916, travelling priests were authorized to adopt the ecclesiastical attire of the place they were in, even though such was not worn in their home diocese. ${ }^{10}$ In 1961, the Archbishops of Montreal and Ottawa issued letters forbidding the wearing of the cassock on the streets, and this was soon followed by other dioceses in Quebec.

On February 24, 1943, the bishops of Quebec issued uniform norms for prenuptial inquiries and for the preparation of marriage files.

${ }^{7}$ Cf. A.A.S., 38 (1946), pp. 281-287; A.A.S., 44 (1952), p. 280. See also, Francis G. Morrisey, "The Development of Particular Canonical Legislation in Canada", in Église et Théologie, 11 (1980), pp. 223-245.

${ }^{8}$ Cf. A.A.S., 44 (1952), p. 280.

${ }^{9}$ Cf. Mandements des Évêques de Québec, 5, p. 318.

${ }^{10}$ Sacred Consistorial Congregation, March 31, 1916, in A.A.S. , 8 (1916), p. 149. 
This was one of the first joint actions of the Quebec bishops in matters of legislation. In 1944, they issued a joint faculty sheet adopted in all the dioceses. In the years that followed, other examples of joint activity among the Quebec bishops were abundant, especially in the area of pastoral letters and instruction of the faithful.

Before the second Vatican Council, the bishops of Canada simplified the rules regarding fasting and abstinence (January 13, 1960). ${ }^{11}$ These rules were mitigated again in 1966 . The few examples of joint action taken in legislative matters paved the way for a concerted effort at the time of Vatican II and in the period immediately following. What seems to be important in these years is not the matter of the legislation, but rather the fact that the bishops were able to work together more readily for the common good.

\section{d. Particular legislation for Oriental Rite Catholics}

One particular area called for special action on the part of the bishops : the immigration to Canada of Catholics of different rites who had to have their spiritual needs provided for. The first immigration to Canada of Oriental Rite Catholics occurred in September 1891. It appears that the Canadian government even favoured the policy of immigration to counter-balance the number of Roman Catholics in the West! The Church was not ready to cope with this new and unexpected situation. The immigrants were first placed under the Latin Ordinaries. On April 12, 1894, the Sacred Congregation for the Propagation of the Faith forbade married priests to immigrate to Latin Rite regions. On

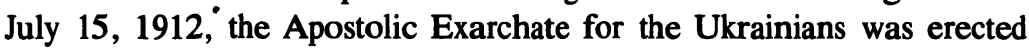
under Bishop Nicetas Budka. It grouped 9 Ukrainian priests and 9 bi-ritual Latin rite priests. The efforts of the Latin rite bishops to provide for the pastoral care of the Orientals have been well documented. ${ }^{12}$ Archbishop Adélard Langevin and Father Albert Lacombe were among the pioneers in this area.

The Holy See issued special norms for the administration of the Ukrainian exarchate on August 18, 1913, and these were revised on May 24, 1930, after Bishop Basil Ladyka succeeded Bishop Budka. Three exarchates were established in 1948, and a fourth one in 1951 .

\footnotetext{
${ }^{11}$ Decision in Canon Law Digest, V, pp. 560-564.

${ }^{12} \mathrm{Cf}$. Gaston Carrière, «Les évêques oblats de l'Ouest canadien et les Ruthènes (1893-1903), "w in Vie Oblate, 33 (1974), pp. 95-119, 157-188.
} 
On November 3, 1956, the ecclesiastical province of Winnipeg for the Ukrainians was established. At that time there were some 425,000 Ukrainians in Canada, of whom 235,000 were Catholics; some 260 priests and 250 sisters worked for the people.

In 1974, a new eparchy was established in New Westminster for the Ukrainians. Since then, the hierarchy has been established for the Slovaks, Maronites, Melkites and Armenians. The presence of Oriental rite Catholics has given a special colour to the Canadian Church, although to date there is little legislation that is specifically Canadian in content. Rather, the bishops are working through their synods to adapt their particular law to new situations. The recent establishment, in Ottawa, of "Holy Spirit Seminary" for the Ukrainians has completed the implementation of the special Canadian norms laid down in 1930.

\section{LEGISLATION IN THE VATICAN II PERIOD}

\section{a. The mode of functioning of the Canadian bishops}

We have already referred to the establishment of the Canadian Conference of Catholic Bishops as an outgrowth of the Plenary Council of Quebec. The establishment of the Conference meant that the Canadian bishops had available a suitable organism for the implementation of the Vatican II decrees.

The implementation of the Constitution on the Liturgy provided an excellent opportunity for the Conference to work together as a group, either in its sectors (English and French), or as a whole. The publication of the National Bulletin on Liturgy provided a suitable means of expression of the bishops' decisions in liturgical matters. Since the period of changes in rites has just about elapsed, the Bulletin has now taken on a new role, that of informing and instructing in liturgical matters. Some twelve decrees were promulgated by the Conference in the years immediately following the Council. Most of these concerned the introduction of the vernacular, the revision of rites and the publication of revised texts. ${ }^{13}$

\footnotetext{
${ }^{13}$ Details of these decisions are to be found in Bulletin of the National Commission on Liturgy, Ottawa, C.C.C. Publications: No. 2, pp. 19-20; No. 8, p. 2; No. 10, p. 3; No. 21, p. 5; No. 23, p. 64; No. 18, p. 220; CCC Official Documents, Nos. $343,345,350$.
} 
Another area of particular concern of the bishops was the reorganization of the marriage court system in the country. The divisions established in 1946 no longer corresponded entirely to the population distribution, particularly at the level of the second instance. A first redistribution was effected in $1965,{ }^{14}$ with the establishment of a new appeal court in Montreal. The number of cases presented for adjudication called for a simplification of the procedural norms to be observed. With the assistance of the Canadian Canon Law Society which had been established in 1966, the bishops presented a number of requests to the Holy See. Many of these were granted, particularly in 1971 and 1974. ${ }^{15}$ This, along with a broadening of the grounds of nullity, has enabled the Canadian courts to process some 3,000 cases annually, against a total of some 200 per annum in the 1960's. The bishops also actively promoted the presence of women in the courts, something that was not foreseen in the 1917 Code and the conciliar documents. Some forty women received their degrees in Canon Law, a number as yet unsurpassed by any other country in the world.

These decisions, and similar ones, were taken by the bishops after extensive consultation among the persons involved in the matter, whether it be in liturgy or in tribunals. The use of professional associations enabled the Conference to rely on expertise found in the country and to involve more people in the decision-making process. This has certainly been one of the characteristics of the mode of functioning of the Conference. At the present time, the particular interests of French and English-speaking groups is making it more difficult to continue this general approach; however, the mode of operation adopted in the postconciliar years has certainly produced its results. In the particular area of Canon Law, the Conference established a Canon Law Commission, composed of a number of bishops and assisted by a group of consultors, most of whom are former presidents of the Canadian Canon Law Society. The Commission was given the responsibility of preparing the new decrees for presentation to the assembly and, subsequently, to the Holy See.

\footnotetext{
${ }^{14}$ Sacred Congregation of Sacraments, letter of August 3, 1965, in Studia Canonica, 1 (1967), p. 126 (Prot. No. $1021 / 64 \mathrm{Vg}$ ).

${ }^{15}$ CCC Official Documents, Nos. 310, 373. Also, SUPREME TRIBUNAL OF THE APOSTOLIC SIGNATURA, Prot. No. 1292/71 Vt.
} 


\section{b. Significant decisions of the Canadian bishops}

Two areas of intense decision-making were referred to above: revision of liturgical law, the re-organization of the marriage courts. However, these are not the only areas of concern of the Conference. Norms regarding change of rite were approved by the Holy See on January $4,1974,{ }^{16}$ providing for a more unified pastoral approach to a sometimes delicate question. The Conference also revised its norms regarding the selection of bishops and has been preparing revisions of these norms as circumstances warrant. ${ }^{17}$

In 1968, the practice of appointing pastors for a term of office, rather than indefinitely, was introduced into certain parts of the country through indults. ${ }^{18}$ On March 19, 1967, the bishops of Quebec agreed to give jurisdiction for hearing confessions to all priests who held confessional faculties. This decision was then taken up by the Conference as a whole and approved on September 8 of the same year, in order to provide for better pastoral care in the country. This decision was one of those most appreciated by priests in the country.

The Conference also revised the norms on mixed marriages and approved these definitively in September 1971. These norms applied both to Latin rite Catholics and to Orientals. The laws regarding the observance of holydays of obligation was simplified on February 14, 1968. ${ }^{19}$ Similarly, the legislation regarding penitential discipline in the country.

Significant efforts were spent at revising the norms for priestly formation in Canada. The work was carried out by each sector, so that there are two programmes of priestly formation for the country. This was necessary in part because of the different education system used in the Provinces. The English-sector norms were approved on May 15, 1980 by the Sacred Congregation for Catholic Education.

Each of these decisions, taken alone, appears rather easy to prepare. But it must be recalled that all this work was being undertaken at the

${ }^{16}$ CCC Official Documents, Nos. 347, 352.

${ }^{17}$ CCC Official Documents, Nos. 177, 404.

${ }^{18}$ For instance, indult of the S.C. for the Clergy, No. 118272/I, August 3, 1968.

${ }^{19}$ CCC Official Documents, No. 140. (Sacred Congregation for the Clergy, February 14, 1968, Prot. No. 116593/D). 
same time as the conciliar decisions were being implemented. Almost every point assigned to the Conference by the Council was implemented, either on a provisional or a permanent basis, by the bishops within a seven-year period. While this work of revising laws was being undertaken, the bishops were also called upon to contribute to the revision of the Code of Canon Law, promulgated January 25th 1983.

\section{c. Revision of Church law}

The Pontifical Commission for the Revision of the Code of Canon Law began its work in earnest in 1967. A number of draft texts were prepared, representing the work of fourteen sub-commissions. As of 1971, the Conference began receiving proposals from the Holy See for the revised Latin Code. The Oriental texts were distributed as of 1978.

Each of the drafts was the object of extensive comment, most of the time favourable. Committees were established throughout the country, enabling canonists and other interested persons to submit recommendations, which were then reviewed by the Canon Law Commission and approved by the Conference. As the process of revision went on, the Conference decided that it would be opportune to collaborate more closely with other Conferences, so that a unified approach could be made to the papal commission. Thus, meetings were held in Dublin (1977) and in Ottawa (1978), grouping the representatives of some sixteen major Conferences.

Now that the Code of Canon Law has been promulgated for the Latin Church, it is interesting to examine the input and influence of the Canadian bishops in the revision. A study of the proposals submitted and of the final text shows that some $80 \%$ of the requests were accepted by the commission, at times even according to the letter. This is a very significant factor. One of the reasons for the success of this undertaking lies in the fact that the bishops, when raising objections against a proposed norm, submitted a revised version stating clearly what they wanted in its place. It was this alternate reading that was often accepted. The influence on the revision of the Oriental Code is still uncertain because only the first round of consultation is completed and the consolidated draft has not yet been made available.

The work of the Canadian Canon Law Society is of paramount importance in this regard, and provides a good model for other forms of joint collaboration with the bishops and the Holy See. Of all the projects undertaken by the bishops during the post-conciliar period, this 
one seems to have produced the greatest results in the area of law. A number of norms approved by the Conference after Vatican II will now have to be revised to bring them in harmony with the new laws.

\section{APPLICATION OF THE 1983 CODE OF CANON LAW}

\section{a. Legislative authority of the Canadian bishops}

One of the areas where the Canadian proposals differed from those of other countries was that of the authority given to Episcopal Conferences to make particular laws for the country. The various drafis at first assigned almost 300 decisions to the Conference in one way or another. However, it was felt here that this removed the individual bishop's right to legislate and would be contrary to the thrust of Vatican II which had defined the diocesan bishop as Vicar of Christ with all the ordinary and immediate authority necessary to govern the particular Church entrusted to his care. To reserve so many decisions to a higher authority, not to mention those which required the intervention of the Holy See, would be to go counter to the conciliar ecclesiology. Consequently, the CCCB (Canadian Conference of Catholic Bishops) constantly requested that the number of reserved decisions be reduced. In the final version, only about one hundred such decisions are now reserved, and some three hundred pertain to the local bishop in his diocese.

On September 16, 1983, the CCCB met to take decisions on some of the matters referred to the episcopal conference in the new law. Such decisions concerned the appointment of pastors for a specific term of office, the authorization granted to lay men and women to act as judges in courts, the revision of legislation regarding the holydays, fast and abstinence, preaching by lay persons, and so forth. These decisions, once taken by the Conference, require confirmation by the Holy See. Since it would not be possible to take all one hundred decisions at the same time, the Conference decided to divide the task and spread it over a number of years. Thus, it is foreseen that each year for the next few ones, there will be further decisions taken. However, many of these decisions require extensive consultation with other groups and cannot realistically be made before serious studies are undertaken.

\section{b. Preparation for eventual synods and a plenary council}

With some 400 canons of the 1752 norms found in the new Code requiring adaptation at the local level to provide better for particular 
needs, we shall see rather intense legislative activity in Canada in the immediate future. However, before embarking on such an enterprise, it would be important to keep a number of points in mind. One of the major shifts in emphasis in the new law could be summarized as follows: in the 1917 Code, authority in the Church derived from the sacrament of Orders; in the 1983 Code, mission in the Church derives from baptism and confirmation. Consequently, the sharing in the triple mission to teaching, sanctifying and serving is no longer the exclusive prerogative of the clergy. Rather, all the faithful, clergy, religious and laity, are called to take up their rightful part in fostering ecclesial communion.

The new Code lays particular emphasis on diocesan synods and plenary councils to enact the new legislation. One of the major advantages of such organisms is that they provide for the active involvement of all members of the faithful in one way or another in drawing up the legislation. It is not good to proclaim that the Church is the Church of the faithful, and yet continue to legislate as if it were the Church of the clergy. It is reasonable to expect that each Canadian diocese will hold a synod within a few years to take the decisions that are of local import. It will be important, though, to make sure that there is a solid base of support and understanding before decisions are taken and implemented. Otherwise, the same mistakes as were made after Vatican II will be repeated: too many changes, too quickly, without understanding of the reasons behind the change.

It is also foreseen that a plenary council can be held for the country. At first sight, it would have appeared preferable to take five or six years to organize such a council before local synods are held, so that the diocesan legislation would proceed from a common vision of Church. However, given the political situation in Canada and the regional disparity, it does not seem likely that such will be the case. Thus, it probably will be necessary to begin with the synods, hoping these will lead to a council. I believe it would be possible to proceed simultaneously with the preparation of both diocesan synods and a plenary council. In this way, mentalities are being prepared for the adapted legislation and the decisions taken reflect a broad base of support where such is possible. In spite of necessary differences, the Canadian bishops have been able to work jointly on preparing common legislation in the past, and indeed for the last 100 years. There seems to be no cogent reason preventing the same in the future, at least as 
things stand now. The organization and preparation of synods and a council would provide an excellent opportunity for some forms of continuing collaborative action and it is to be hoped that such will be readily applied.

\section{CONCLUSION}

At the end of this bird's-eye view of the legislative activity of the Canadian bishops, a number of conclusions can be drawn. Firstly, the desire for collaborative action must be noted and underscored. Because of this concern for a unified vision of Church, the bishops, according to the needs and mentality of the times, have responded to the call to provide the People of God with a Church legislation that is neither repressive nor too lax. The period of Jansenism which ran its course during the episcopacy of Bishop de St-Vallier, and again during the nineteenth century, is not evident in the contemporary legislative enactments of the bishops.

A second conclusion is that when the bishops legislated according to matters and manners entrusted to them, the Holy See was willing to listen and approve. This points out the need of continuing dialogue with Rome when matters require particular attention. The recognition given to the suggestions for the Code is of particular significance and shows how well-prepared documents can influence, not only the Canadian Church, but also the Church at large.

A third point is that any legislation today will have to be prepared in consultation with the faithful. It would be totally unfair to expect that the bishops have all the expertise required in all matters affecting the Church. The expansion of knowledge and the multiplication of situations requiring immediate attention call for a wider base for the enactment of legislation. The example of the bishops in the past augures well for the future in this regard.

A fourth point to recall is that the Canadian Church is but a small part of the Church universal, with some $1.5 \%$ of the world's Catholics living within the territory of the country. Nevertheless, the local situations encountered here are often repeated elsewhere and whatever assistance the bishops of Canada can give to smaller Churches in drafting new legislation will be of immense import for the development and growth of a truly Catholic Church. The number of persons coming 
to Canada to study Canon Law from other countries is an indication in some way of the respect held for the legislative activity of the Canadian Church and for its concern with the appropriate application of the law.

Paul VI said that the new law is to be an "instrument of grace", one that leads the faithful closer to the Lord. Canonists are called upon to "deepen the work of the Spirit", seeing where the Holy Spirit is leading the Church and to provide for structures and institutions that will protect and enhance this divine intervention in our milieu. This is what is being done and what will, hopefully, continue in the years ahead. 